\title{
Redo laparoscopic repair of benign esophageal disease
}

\author{
Jon O. Wee, MD
}

Laparoscopic fundoplication for gastroesophageal reflux disease has been associated with excellent symptom control. Compared with medical treatment, laparoscopic Nissen fundoplication has shown favorable control of typical reflux symptoms. However, in approximately $2 \%$ to $17 \%$ of patients, surgical treatment fails. The role of reoperative repair for reflux disease and the factors that contribute to it are examined. (J Thorac Cardiovasc Surg 2012;144:S71-3)

Approximately $44 \%$ of patients experience reflux-related symptoms once a month and approximately $7 \%$ to $10 \%$ of patients experience reflux-related symptoms on a daily basis. ${ }^{1}$ Most of these conditions are treated with diet modifications and medications. Proton pump inhibitors, the most popular treatment, generate more than $\$ 13$ billion in revenue and are the third most commonly prescribed drug class. ${ }^{2,3}$ However, more recent data have indicated an increase risk of osteoporosis and fractures, increased Clostridia dificille infections and pneumonia, and increased interaction with cardiac medications with chronic proton pump inhibitor use. ${ }^{4,5}$ Additionally, chronic histamine-2 blockers have been associated with some cognitive dysfunction. ${ }^{6}$ Patients with severe chronic obstructive pulmonary disease are also more prone to exacerbations when accompanied by gastroesophageal reflux disease (GERD) symptoms. ${ }^{7}$

Although some debate remains regarding medical vs surgical correction of reflux disease, a 2010 Cochrane systematic review of randomized controlled trails demonstrated an improved outcome after laparoscopic Nissen fundoplication. ${ }^{8}$ In addition, a meta-analysis of almost 1700 patients demonstrated a decreased incidence of adenocarcinoma and increased regression of Barrett's esophagus, supporting the benefit of surgical correction of reflux disease. $^{9}$

The long-term results after surgery have demonstrated high satisfaction for up to $97 \%$ of patients at 5 years. ${ }^{10-13}$ However, $2 \%$ to $17 \%$ of patients have some level of failure after surgery. ${ }^{14}$ These might be related to recurrent reflux disease, regurgitation, or dysphagia. Approximately $4 \%$ to $6 \%$ of patients have severe, persistent, and refractory symptoms that require reoperative therapy.

From the Division of Thoracic Surgery, Brigham and Women's Hospital, Boston, Mass.

Disclosures: Authors have nothing to disclose with regard to commercial support.

Presented at the 3rd International Minimally Invasive Thoracic Surgery Summit, Boston, Massachusetts, October 7-8, 2011.

Received for publication Nov 14, 2011; accepted for publication March 22, 2012; available ahead of print May 18, 2012

Address for reprints: Jon O. Wee, MD, Division of Thoracic Surgery, Brigham and

Women's Hospital, 75 Francis St, Boston, MA 02115 (E-mail: jwee@ partners.org). $0022-5223 / \$ 36.00$

Copyright (C) 2012 by The American Association for Thoracic Surgery

doi:10.1016/j.jtcvs.2012.03.067

\section{CAUSES OF FAILURE}

The common causes of failure include recurrent hiatal hernia, a slipped or displaced wrap, too tight of a wrap, a misplaced wrap, disruption of the wrap, or a missed diagnosis. ${ }^{15}$ The hiatal hernia is the most common cause of failure. This results in migration of the wrap above the hiatus and can result in both reflux and dysphagia. ${ }^{16,17}$ It might be related to inadequate closure of the crural fibers after repair or an innate weakness within the fibers that predisposes it to dilation. ${ }^{17}$ Some have argued for the use of mesh repair in the case of large hiatal openings. ${ }^{18}$ A prospective randomized trial using a biologic prosthesis demonstrated a $60 \%$ reduction in hernias at 6 months.

Some of this could also be related to inadequate mobilization of the esophagus or a short esophagus. ${ }^{19}$ Although the existence of a true shortened esophagus has been debated, chronic damage from reflux and compression from a hiatal hernia can result in difficulty placing the gastroesophageal junction comfortably in the abdomen..$^{20,21}$

A slipped or displaced wrap can result when the body of the stomach slides above the wrap, resulting in an hourglass stomach. The portion of stomach above the wrap can cause severe reflux symptoms, because it serves as a reservoir. The wrap also becomes obstructive, causing severe dysphagia symptoms. A misplaced wrap can also result in a twisted or asymmetric wrap, leading to recurrent reflux. This usually occurs when the wrap is constructed using the body of the stomach as opposed to the fundus. Finally, physiologic factors such as obesity and straining also contribute to the recurrence of symptoms. ${ }^{15,17,22}$

\section{EVALUATION}

Although a recurrence of symptoms such as heartburn can lead to a presumptive diagnosis of recurrence, symptoms alone have not correlated well with actual recurrence. ${ }^{23}$ A University of California, San Francisco, study of 822 patients demonstrated that only $70 \%$ of patients with a GERD diagnosis had positive findings on a $\mathrm{pH}$ study. ${ }^{24}$ Heartburn and regurgitation were as common in those with a confirmed study as in those without. Hence, symptoms alone are not enough to confirm recurrence. Postoperative monitoring of GERD will result in an abnormal $\mathrm{pH}$ in only $20 \%$ of patients. ${ }^{25}$ An objective evaluation remains critical to the evaluation. This includes upper 


\section{Abbreviation and Acronym \\ GERD $=$ gastroesophageal reflux disease}

gastrointestinal/barium swallow, $\mathrm{pH}$ monitoring, manometry, and upper endoscopy.

A barium contrast study and endoscopy are important in the evaluation of the anatomy of the wrap. It can illustrate the location of the wrap above or below the hiatus, as well as the geometry of the wrap. Some slipped and twisted wraps can be identified by inspection using endoscopy. ${ }^{26}$ Manometry is also important to rule out a missed diagnosis such as achalasia. ${ }^{15}$

$\mathrm{pH}$ monitoring remains the reference standard, with sensitivity, specificity, and accuracy approaching $96 \%{ }^{27} \mathrm{Com}-$ bined impedance and $\mathrm{pH}$ monitoring can also detect both acid and nonacid reflux disease. Studies have demonstrated a high correlation with GERD with high reproducibility. ${ }^{28}$ The determination of the bolus transit time can also be used as an evaluation of esophageal function.

\section{SURGICAL GOALS}

Reoperative surgery for reflux disease should start with reestablishing the normal anatomy. This involves taking down the adhesions surrounding the wrap and hiatus. The wrap should be fully mobilized. The normal gastric anatomy should be achieved by unfurling the wrap from the gastroesophageal junction. One must be careful to avoid injury to the vagus nerves in this process. Once a normal gastric anatomy has been achieved, the hiatus and esophagus can be fully examined to better identify the cause of failure. Additional mobilization of the esophagus can be achieved through the hiatus, separating it from the aorta and pericardium. Additionally, the esophageal length and the need for a Collis gastroplasty can be determined. ${ }^{19-21}$

Once the esophageal length as been addressed, the wrap should be reformed over a bougie. ${ }^{29}$ Generally, a loose Nissen fundoplication is adequate for repair. This can be performed by using a large bougie to help size the wrap. Some patients in whom the initial complaint is dysphagia might benefit from a Toupet fundoplication, although studies have favored laparoscopic Nissen fundoplication for long-term treatment of reflux, with very little difference in dysphagia symptoms. ${ }^{30-33}$ Hiatal closure is then accomplished. If a hiatal hernia is the cause of failure, consideration should be made to place mesh support on the crura. ${ }^{18}$

\section{OUTCOMES}

A large meta-analysis of more than 4500 cases by Furnee and colleagues ${ }^{15}$ reported the largest review of reoperative fundoplication and included both open and laparoscopic series (Table 1). Mortality after reoperation was $1.3 \%$,
TABLE 1. Recurrent symptoms and causes of failure

\begin{tabular}{lc}
\multicolumn{1}{c}{ Variable } & Incidence (n) \\
\hline Common recurrent symptoms & 4750 \\
Recurrent reflux & $1912(41.7)$ \\
Dysphagia & $760(16.6)$ \\
Recurrent reflux and dysphagia & $184(4.0)$ \\
Anatomic abnormality & $114(2.5)$ \\
Gas bloat syndrome & $31(0.7)$ \\
Miscellaneous & $148(3.2)$ \\
Not reported & $1435(31.3)$ \\
Anatomic causes of failure & 3175 \\
Intrathoracic wrap migration & $885(27.9)$ \\
Wrap disruption & $722(22.7)$ \\
Telescoping & $448(14.1)$ \\
Paraesophageal hiatal herniation & $195(6.1)$ \\
Hiatal disruption & $167(5.3)$ \\
Tight wrap & $168(5.3)$ \\
Stricture & $60(1.9)$ \\
\hline Data in parentheses are percentages. Data from Fernee
\end{tabular}

although none occurred in the laparoscopic group. Symptomatic success was seen in $81 \%$ of the laparoscopic patients; $78 \%$ of the patients had successful objective outcomes. Common complications included gastric or esophageal perforations, although most were recognized immediately and corrected laparoscopically. Khajanchee and colleagues ${ }^{34}$ reported a laparoscopic series of 13 years that also demonstrated success in $75 \%$ of reoperative patients, with complete to near complete resolutions of symptoms. An additional 14\% had improved symptoms. ${ }^{34}$ Of these patients, $81 \%$ had wrap herniation seen on the upper gastrointestinal study. The findings from the quality of life evaluations after reoperative surgery also approached general population norms. ${ }^{35,36}$

\section{CONCLUSIONS}

Reoperative laparoscopic surgery for recurrent reflux symptoms can be achieved with minimal mortality risk. A full evaluation is necessary to understand the cause of recurrent symptoms. Symptoms alone are often not enough and often do not correlate with actual recurrence. The surgical goals are to return the normal gastric anatomy and evaluate the entire hiatal complex before reforming the wrap. Objective and symptomatic success can be achieved in approximately $80 \%$ to $90 \%$ of patients and should be considered for persistent recurrent disease.

\footnotetext{
References

1. Dent J, El-Serag HB, Wallander MA, Johansson S. Epidemiology of gastrooesophageal reflux disease: a systematic review. Gut. 2005;54:710-7.

2. Vakil N. Proton pump inhibitors for dyspepsia. Dig Dis. 2008;26:215-7.

3. Everhart JE, Ruhl CE. Burden of digestive diseases in the United States part I: overall and upper gastrointestinal diseases. Gastroenterology. 2009;136:376-86.

4. Ito T, Jensen RT. Association of long-term proton pump inhibitor therapy with bone fractures and effects on absorption of calcium, vitamin $\mathrm{B}_{12}$, iron, and magnesium. Curr Gastroenterol Rep. 2010;12:448-57.
} 
5. Laheij RJ, Sturkenboom MCJM, Hassing RJ, Dieleman J, Stricker BHC, Jansen JBMJ. Risk of community-acquired pneumonia and use of gastric acidsuppressive drugs. JAMA. 2004;292:1955-60.

6. Boustani M, Hall KS, Lane KA MS, Hisham A, Sujuan G, Unverzagt F, et al. The association between cognition and histamine-2 receptor antagonists in African Americans. J Am Geriatr Soc. 2007;55:1248-53

7. Rascon-Aguilar IE, Pamer M, Wludyka, P, Cury, J, Coultas D, Lambiase L, et al. Role of gastroesophageal reflux symptoms in exacerbations of COPD. Chest. 2006;130:1096-101.

8. Wileman SM, McCann S, Grant AM, Krukowski ZH, Bruce J. Medical versus surgical management for gastro-oesophageal reflux disease (GORD) in adults. Cochrane Database Syst Rev. 2010;3:CD003243.

9. Chang EY, Morris CD, Seltman AK, O'Rourke RW, Chan BK, Hunter JG, et al. The effect of antireflux surgery on esophageal carcinogenesis in patients with Barrett esophagus: a systematic review. Ann Surg. 2007;246:11-21.

10. Dallemagne B, Weerts J, Markiewicz S, Dewandre JM, Wahlen C, Monami B, et al. Clinical results of laparoscopic fundoplication at ten years after surgery. Surg Endosc. 2006;20:159-65.

11. Cowgill SM, Gillman R, Kraemer E, Al-Saadi S, Villadolid D, Rosemurgy A. Ten-year follow up after laparoscopic Nissen fundoplication for gastroesophageal reflux disease. Am Surg. 2007;73:748-53.

12. Granderath FA, Kamolz T, Schweiger UM, Pointner R. Laparoscopic antireflux surgery for gastroesophageal reflux disease: experience with 668 laparoscopic antireflux procedures. Int J Colorectal Dis. 2003;18:73-7.

13. Kelly J, Watson D, Chin K, Devitt P, Game P, Jamieson G. Laparoscopic Nissen fundoplication: clinical outcomes at 10 years. J Am Coll Surg. 2007; 205:570-5.

14. Morgenthal CB, Shane S. The durability of laparoscopic Nissen fundoplication: 11-year outcomes. J Gastrointest Surg. 2007;11:693-700.

15. Furnee EJ, Draaisma W, Broeders I, Gooszen H. Surgical reintervention after failed antireflux surgery: a systematic review of the literature. $J$ Gastrointest Surg. 2009;13:1539-49.

16. Campos GM, Peters JH, DeMeester TR, Oberg S, Crookes PF, Tan S, et al. Multivariate analysis of factors predicting outcome after laparoscopic Nissen fundoplication. J Gastrointest Surg. 1999;3:292-300.

17. Horgan S, Pohl D, Bogetti D, Eubanks T, Pellegrini C. Failed antireflux surgery: what have we learned from reoperations? Arch Surg. 1999;134:809-17.

18. Oelschlager BK, Pellegrini CA, Hunter J, Soper N, Brunt M, Sheppard B, et al. Biologic prosthesis reduces recurrence after laparoscopic paraesophageal hernia repair: a multicenter, prospective, randomized trial. Ann Surg. 2006;244: 481-90.

19. Gastal OL, Hagen JA, Peters JH, Campos GM, Hashemi M, Theisen J, et al. Short esophagus: analysis of predictors and clinical implications. Arch Surg. 1999;134: 633-8.

20. Altorki NK, Yankelevitz D, Skinner DB. Massive hiatal hernias: the anatomic basis of repair. J Thorac Cardiovasc Surg. 1998;115:828-35.

21. Maziak DE, Todd TR, Pearson FG. Massive hiatus hernia: evaluation and surgical management. J Thorac Cardiovasc Surg. 1998;115:53-62.
22. Morgenthal CB, Lin E, Shane MD, Hunter JG, Smith CD. Who will fail laparoscopic Nissen fundoplication? Preoperative prediction of long-term outcomes. Surg Endosc. 2007;21:1978-84.

23. Galvani C, Fisichella PM, Gorodner MV, Perretta S, Patti MG. Symptoms are a poor indicator of reflux status after fundoplication for gastroesophageal reflux disease: role of esophageal functions tests. Arch Surg. 2003;138:514-9.

24. Patti MG, Diener U, Tamburini A, Molena D, Way LW. Role of esophageal function tests in diagnosis of gastroesophageal reflux disease. Dig Dis Sci. 2001;46: 597-602.

25. Lord RV, Kaminski A, Oberg S, Bowrey DJ, Hagen JA, DeMeester SR, et al. Absence of gastroesophageal reflux disease in a majority of patients taking acid suppression medications after Nissen fundoplication. J Gastrointest Surg. 2002;6:3-10

26. Juhasz A, Sundaram A, Hoshino M, Lee TH, Filipi CJ, Mittal SK. Endoscopic assessment of failed fundoplication: a case for standardization. Surg Endosc. 2011;25:3761-6.

27. Johnsson F, Joelsson B, Isberg PE. Ambulatory 24 hour intraesophageal pH monitoring in the diagnosis of gastroesophageal reflux disease. Gut. 1987;28 1145-50.

28. Mainie I, Tutuian R, Shay S, Vela M, Zhang X, Sifrim D, et al. Acid and non-acid reflux in patients with persistent symptoms despite acid suppressive therapy: a multicentre study using combined ambulatory impedance-pH monitoring. Gut. 2006;55:1398-402.

29. Patterson EJ, Herron DM, Hansen PD, Ramzi N, Standage BA, Swanström LL. Effect of an esophageal bougie on the incidence of dysphagia following Nissen fundoplication: a prospective, blinded, randomized clinical trial. Arch Surg. 2000;135:1055-62

30. Horvath KD, Jobe BA, Herron DM, Swanstrom LL. Laparoscopic Toupet fundoplication is an inadequate procedure for patients with severe reflux disease. $J$ Gastrointest Surg. 1999;3:583-91.

31. Kamolz T, Granderath FA, Bammer T, Wykypiel H Jr, Pointner R. "Floppy" Nissen vs. Toupet laparoscopic fundoplication: quality of life assessment in a 5-year follow-up (part 2). Endoscopy. 2002;34:917-22.

32. Oleynikov D, Eubanks TR, Oelschlager BK, Pellegrini CA. Total fundoplication is the operation of choice for patients with gastroesophageal reflux and defective peristalsis. Surg Endosc. 2002;16:909-13.

33. Patti MG, Robinson T, Galvani C, Gorodner MV, Fisichella PM, Way LW. Total fundoplication is superior to partial fundoplication even when esophageal peristalsis is weak. J Am Coll Surg. 2004;198:863-70.

34. Khajanchee YS, O'Rourke R, Cassera MA, Gatta P, Hansen PD, Swanström LL. Laparoscopic reintervention for failed antireflux surgery: subjective and objective outcomes in 176 consecutive patients. Arch Surg. 2007;142:785-92.

35. Granderath FA, Kamolz T, Schweiger UM, Pointner R. Failed antireflux surgery: quality of life and surgical outcome after laparoscopic refundoplication. Int J Colorectal Dis. 2003;18:248-53.

36. Kamolz T, Granderath PA, Bammer T, Pasiut M, Wykypiel H Jr, Herrmann R Mid- and long-term quality of life assessments after laparoscopic fundoplication and refundoplication: a single unit review of more than 500 antireflux procedures. Dig Liver Dis. 2002;34:470-6. 